\title{
Linkages between Trade Openness, Productivity and Industrialization in Nigeria: A Co-integration Test
}

\author{
Ilemona Adofu ${ }^{1} \&$ Innocent Okwanya ${ }^{1}$ \\ ${ }^{1}$ Department of Economics, Federal University Lafia, Nigeria \\ Correspondence: Ilemona Adofu, Department of Economics, Federal University Lafia, Nigeria.
}

Received: November 2, 2017

Accepted: December 4, 2017 Online Published: December 17, 2017

doi:10.5430/rwe.v8n2p78

URL: https://doi.org/10.5430/rwe.v8n2p78

\begin{abstract}
This study examines the effect of trade openness and total factor productivity on industrial output in Nigeria. The data used for this analysis covers the period 1981-2015. The paper employs the VAR model in estimating the effect of trade openness on industrial output. The impulse response function and the variance decomposition are used to examine the response of industrial output to shocks in trade openness and total factor productivity. The results show that trade openness has a positive increasing effect on industrial output in Nigeria while the effect of total factor productivity on industrial output is found to be insignificant. The impulse response function shows over the long run period tfP negative effect on industrial output in Nigeria. The findings of this study certainly have important policy implications: it suggests that policies geared towards increasing trade openness should be encouraged as this tends to improve industrial output. This study contributes to economics literature by looking at the degree to which trade openness and total factor productivity influence industrial output in Nigeria.
\end{abstract}

Keywords: industrial output, trade openness, total factor productivity, VAR

\section{Introduction}

One important determinant of growth which has attracted much debate in recent growth studies is openness to trade. Developing nations like Nigeria, in the past had reasons to restrict trade as a policy towards protecting domestic industries, but in the wake of globalization, most of this countries have been forced to reconsider their economic policy stance in terms of trade openness. This is because as Adenikinju and Olofin (2000) noted, trade openness and policy of trade give rise to industrial development. Trade of a country is a key determinant for the improvement of a country's industrialization. Moreover, development experienced by a country brings some changes in trade structure on the basis of endowments and comparative advantage (Hultman, 1967).

Trade policies interlink with industrial growth can be explained in a number of way. Scale efficiency is enlarged through increasing the scope of domestic industrial sector and also an open trade regime effects high competition in world market, which further enhance firms in a country to trail and take up modern technology. Furthermore, it enhances efficiency. In addition, an open trade regime lessens limitations caused by foreign exchange as witnessed in case of developing nations. It also causes great development in technological progress. (Lucas, 1988, Grossman and Helpman, 1989; 1991; and Romer, 1990)

In the opinion of Obasan and Adediran (2010), productivity growth in agriculture in developed and developing countries tends to be higher than in manufacturing sector. The macro and micro studies on manufacturing enterprises carried out in recent time has established the consequences of trade liberalization for the industrial sector in African countries. Contemporary economies are largely characterized by inter-border trade. This is made possible by differences in the factor endowment of each economy as postulated by the popular theories of comparative analysis and absolute advantages.

According to Odior (2013), higher productivity is a sure means of enhancing economic growth and rising standards of living in any country. Expressing and executing effective productivity schemes have helped to jerk many economies out of worldwide recession and set them on the path of growth. This would imply a major leap in output of goods and services. Increasing productivity should be the concentration because many other nations that have found themselves in the same dilemmas have resolved them through productivity improvement schemes. For 
instance, Japan from the end of the World War II and the United States of America from the 1970s have made high productivity as the centre point of their economic planning and the results have been resounding (Anyanwu, 2004).

In the opinion of Alao (2010), the route to economic recovery and growth may necessitate increasing productive inputs such as land, labour, capital and technology and or swelling their productivity through with a bumpy-road to steadiness in the face of the global economic meltdown. But the variations in the macroeconomic policy have become increasingly momentous within the productivity sector as manufacturing has become more capitalized and more reliant on international markets, as a result of this, the sector is being more susceptible to disparities in interest rates, exchange rates, the size of gross domestic product, foreign direct investment and other macroeconomic variables.

The ability of nation to fully utilize his factor endowment, both natural and human, has been premised on industrialization. It is a significant catalyst in economic growth of any nation and plays a significant role in economic growth. An industrialized nation is propelled towards structural transformation and diversification of economy. As Obasan and Adediran, (2010) observed, it helps a country to fully utilize its factor endowment and to depend less on foreign supply of finished goods or raw materials for its economic growth, development and sustainability. In the words of Okafor, (2005) there is considerable interest especially in developing economies. This is because it is believed that a deliberate and sustained application and combination of an appropriate technology, infrastructure managerial expertise and other important resources will guarantee economic growth and development. There are structural changes in certain major aspects of the Nigerian economy that has forced economist and policy makers into thinking of changing some of the structural foundation to favour economic growth. Some of this structural change is that of exchange rate fluctuation. Exchange rate in Nigeria witnessed a radical change from the long operated fixed system between the 1960s and the first half of the 1980s. It shifted dramatically from the second half of 1986 to a flexible regime when the structural adjustment programmes (SAP) began. Since the move to liberalized system, the economy witnessed series of changes that have substantially affected the trend and stability of the rate. In other words, in Nigeria, it has always been realized that economic development requires growth with structural change. In considering the Nigerian economic growth, that has been adversely affected by the prolonged economic recession occasioned by the collapse of the world oil market from the early 1980 and the attendant sharp fall in foreign exchange earnings. The economy's problems may also include dysfunctional social and economic infrastructure, excessive dependence on imports for consumption and capital goods, poor institutional framework and management strategies, unprecedented fall in capacity utilization rate in industry and neglect of the agricultural sector, among others (Adesina, 1992). These have led to the problem of economic diversification to other sector of the economy and also resulted in fallen incomes and devalued standards of living amongst Nigerians.

Considering the place of industrialization in economic growth and the attendant effect of trade openness and productivity increase, this study is to analyze the linkage between trade openness, productivity and industrialization in Nigeria.

\section{Literature Review}

Ebong, Udo and Obafemi (2014) examined the nature of the influence globalization might have exerted on the industrial development of Nigeria over a period of five decades (1960-2010). Based on the Engle-Granger two-step and Johansen Cointegration tests, the vector auto regressions technique was used within an error correction framework. Results clearly showed that globalization had significant impacts on industrial development in Nigeria. Specifically, trade openness had a positive influence on industrial development. This suggested that increasing the level of trade with the rest of the world would create opportunities to export local raw materials and import necessary inputs into the industrial process. In contrast, financial liberalization adversely impacted on industrial development. Policies were required to reverse the tide of capital flight from the country and direct resources towards developing the country's industrial sector.

Ugwuanyi and Nkem (2017) carried out a study to analyze industrialization drivers and Nigeria economic growth between the periods 1980 to 2014 using time series data. The methodology employed was Unit Root Test, Co-integration Test, Error Correction model and Granger Causality Test in determining the objectives of the research. Findings revealed that Foreign Direct Investment (FDI), Financial System Development which is proxy with Aggregate Bank Lending (ABL) and Exchange Rate (EXR) significantly stimulate the Nigeria economy while Trade Openness negatively influences economic growth in the long run. They concluded based on their results that Foreign Direct Investment, Aggregate Bank Lending and Exchange Rate are key determinants of industrialization that helps to achieve the sustainable level of industrial development and hence promote economic growth. They went further to recommend creation of favourable economic environment to encourage more inflows of foreign investment and 
more administrative sweeteners like low operation costs, low tariffs be put in place to further encourage foreign investors as these will help in stimulating industrialization and hence promote growth in the Nigeria economy.

In his study, Tawose (2012), set out to find out the effect of public expenditure on industrial sector productivity in Nigeria. Ordinary least square multiple regression was adopted to carry out analysis on the relationship that exist between public expenditure and industrial sector productivity. In the model adopted, Index of industrial Production (IIP) serves as proxy for industrial productivity, while Total Government Expenditure (GEXP), Government Expenditure on Administration (GADM), Government Expenditure on Economic Services (GESC), and Government Expenditure on Social and Community Services (GSCS) and Government Expenditure on Transfer (GTRS) were proxies for government expenditure. The regression results showed that both government expenditure on administration and government expenditure on economic services have negative relationships with industrial productivity. This implies that when GADM and GECS are increasing, the IIP falls. Also when GSCS and GTRS are increasing, IIP also increases. The impact of each independent variable either negative or positive on industrial productivity is insignificant. These findings revealed the fundamental reasons why Nigerian economy remain underdeveloped, despite the huge amount spend every year for the past 52 years since her political independence. It was found out that all the explanatory variables in the model collectively explained about $86 \%$ changes in the behavior of industrial productivity in Nigeria. Generally, the research discovered that the public expenditure process in Nigeria as a whole is marred with mismanagement, misallocation allocation of resources and lack of leadership focus. In recognizing the present ugly situation of public expenditure process that lack transparency and accountability, it therefore became imperative that only a well-designed public sector accountability reform package targeted at improving the industrial sector performance indicators positively can reverse the relationship between public expenditure and industrial productivity. Despite the fact that the presence of funds is a good instrument to attain industrial productivity, there is need for open and competitive tender arrangements for government contracts; the establishment of a "Due Process" mechanism that vets and eliminates excess "fat" from government contracts; massive anticorruption campaigns involving all public officials and the political appointees; and public sector reforms to reduce, if not completely eliminate, the opportunity for corruption.

Umoru and Eborieme, (2013), investigated the relation between trade liberalization and industrial growth in Nigeria. Adopted in the study is the human capital model of endogenous growth with modifications for trade liberalization within the Nigerian context. In the empirical investigation of the aggregate function of industrial output growth in Nigeria, co-integration and error correction estimation approaches were utilized. A unique co-integral relation between industrial production and the explanatory variables in the study is found. In order to determine the short-run dynamics around the equilibrium relationship, we estimated an error correction model [ECM]. The empirical findings in this study have it that there is a positive and significant correlation between trade liberalization and industrial growth in Nigeria, structural deregulation had positive impact industrial growth in Nigeria, Nigerian industries are labour intensive, industrial production responded negatively and insignificantly to capital formation in Nigeria, industrial growth is cumulative and self-sustaining in Nigeria. The result however does not provide evidence of significance of structural deregulation over the period of short-run analysis. The policy implications are simple. The results of the study suggest the need for government to embark on comprehensive implementation of trade liberalization policies in order to accelerate and sustain industrial growth in Nigeria. However, the implementation of trade liberalization polices should be done with a delay caution.

Aluko, Akinola and Fatokun (2004) in their study of the impact of globalization on the Nigerian manufacturing sector with particular reference to textile firms selected from Lagos, Asaba and Kano employed both qualitative and quantitative techniques in the collection of the relevant data while parametric and non-parametric methods were adopted in the data analysis. The study makes use of a sample of 630 respondents. Findings from this study shows that globalization has had an inverse effect on the manufacturing sector. In particular, the result shows that globalization has strong adverse effects on capacity utilization in the manufacturing sector. They concluded that, Nigeria and her manufacturing firms are not fully ready for the trials of globalization.

\section{Nigeria Trade Policy and Industrial Growth: An Overview}

Smith (1776) posited that it is always safer to allow the economy to be propelled by an invisible hand, that is, the forces of competition motivated by industrial self-interest. This position forms the foundation for the policy of trade liberalization. Smith's (1776) position for trade liberalization was premised on the role which division of labour plays in economic growth. For example, expansion of international trade is an important method of widening the market and of promoting the division of labor while trade restrictions limit the size of the market, diminishes the scope for international specialization, and thus lowering domestic productivity. 
Ricardo (1817), approximating Smith (1776) position, emphasized the role of "comparative advantage, market mechanism" and "competition" in the growth of the economy. According to the classical theory of international trade, "free trade is the best policy" and it leads to the optimization of world's resources through international division of labour. Indeed, these authors long viewed international trade as engine of economic growth and hence as engine of mutual economic gain among countries (Umoru and Eborieme, 2013).

The Nigeria Government had made concerted effort at policy that will be beneficial to the growth of the economy over the years. Some of the trade policy reforms that have been adopted over the years according to Umoru and Eborieme, (2013), include granting of special tax incentives and tax holidays to enable local industries build up adequate funds for expansion and to encourage firms invest in economically disadvantaged areas, the partial abolition of import license scheme, reduction of corporate income tax rate and introduction of tax-free dividends for foreign persons and to encourage local research and development. Others include the establishment of export credit guarantee and insurance scheme to assist Nigeria companies compete meritoriously in the international market, the proclamation of export incentives decree in which numerous inducements to enhance export promotion were specified, export stimulation loan (ESL) scheme to provide for foreign producers that require imported inputs essential to the production of export products, data bank, raw material research and development council (RMROC), project development agency (PRODA), federal institute of industrial research (FIIR), export processing zones (EPZs), Nigeria investment promotion council, simplification of industrial licensing, deregulation of the exchange market and devaluation of the naira, opening of domiciliary account to keep firms' export earnings in foreign currencies, government institutional supports through the establishment of industrial development coordinating committee (IDCC), government grant of 140 percent tax relief to firms in respect of research and development of raw materials.

\section{Theoretical Framework}

This study applies Gerschenkron theory of economic deprivation. Our choice of this theory is premised on the position to treat Nigeria as a newly industrializing country. The argument of this theory is that industrial growth emanates from the context of economic deprivation. According to this position, a number of benefits accrue to industrial stragglers that may create a speedy dive out of backwardness into sustained economic growth. This is partly based on the observation that some industrial stragglers (of the 18th and 19th centuries) had the tendency to grow at a faster rate than their predecessors. This can be seen in the rapid industrial growth in Japan at the turn of the century and that in Taiwan in the 1960s and1970s.

The main thrust of the deprived economy model is the beginning of industrial growth and is built on underdevelopment as the starting point. It predicts that as more endowed countries advance and backwardness deepens, the underprivileged society will become increasingly sensitive to the contrast. As social tension increases a vast effort is made to bridge the gap and a desire for the benefits of industrial growth is born. Such growth is deemed possible as backwardness conveys a number of advantages on backward nations. The more backward a national economy, the more sophisticated will be the industrial equipment, technology and plant it can select for its manufacturing development. It will be able to import the most modern machines with the concomitant advantage of enjoying the most significant economies of scale currently available.

Gerschenkron's theory has a discrete advantage in that it identifies the position of the present less developed countries (LDCs) in relative to the world market. Their position is essentially different from that of the advanced countries on the eve of their industrialization. However, the twin problems as to where the foreign exchange for financing this will come from and how to solve the balance of payments problems that may ensue need to be addressed given that the major exports of these countries are primary productions. This is the theoretical link between industrialization and globalization.

\section{Methodology}

This study employed annual time series data sourced from CBN statistical Bulletin (2016) and World Bank Development Indicator (2016) from 1981 to 2015. The data used in this study include: Industrial output [MOP] (2010 constant basic prices in billions of dollars), Trade openness [TOP] (sum of exports and imports of goods and services measured as a share percentage of RGDP), total factor productivity [TFP] (measured at constant national price $2011=1$ ), and real GDP [RGDP] (2010 constant basic prices in billions of dollars).

To achieve the main objective of this study which is to examine the effect of trade openness and total factor productivity on industrial output in Nigeria we use the Vector Autoregressive (VAR) model. The VAR model was adopted because we are interested in knowing the influence of trade openness and factor productivity on industrial output in Nigeria. The impulse response function and the variance decomposition analysis were there after used to 
identify the source of shocks and the degree of shocks the variables has on industrial output. The VAR model is specified thus:

$$
\begin{gathered}
M O P_{t}=\alpha_{1}+\sum_{i=1}^{k} \beta_{11} M O P_{t-i}+\sum_{i=1}^{k} \beta_{12} R G D P_{t-i}+\sum_{i=1}^{k} \beta_{13} T O P_{t-i}+\sum_{i=1}^{k} \beta_{14} T F P_{t-i}+u_{1 t} \\
R G D P_{t}=\alpha_{2}+\sum_{i=1}^{k} \beta_{21} M O P_{t-i}+\sum_{i=1}^{k} \beta_{22} R G D P_{t-i}+\sum_{i=1}^{k} \beta_{23} T_{O P} P_{t-i}+\sum_{i=1}^{k} \beta_{24} T F P_{t-i}+u_{2 t} \\
T_{O P P_{t}}=\alpha_{3}+\sum_{i=1}^{k} \beta_{31} M O P_{t-i}+\sum_{i=1}^{k} \beta_{32} R G D P_{t-i}+\sum_{i=1}^{k} \beta_{33} T O P_{t-i}+\sum_{i=1}^{k} \beta_{34} T F P_{t-i}+u_{3 t} \\
T_{F P} P_{t}=\alpha_{4}+\sum_{i=1}^{k} \beta_{41} M O P_{t-i}+\sum_{i=1}^{k} \beta_{42} R G D P_{t-i}+\sum_{i=1}^{k} \beta_{43} T_{O P} P_{t-i}+\sum_{i=1}^{k} \beta_{44} T F P_{t-i}+u_{4 t}
\end{gathered}
$$

Where $\alpha_{\mathrm{i}}$ and $\beta_{\mathrm{ij}}$ are parameters to be estimated; $\mathrm{u}_{\mathrm{it}}$ are innovations or shocks and follows a white noise process; and $\mathrm{k}$ is the maximum lag.

The variables were also tested for the presence of unit root. It is common for time series data to have unit root which will make them non-stationary. When variables are not stationary at level but stationary at first difference, it is possible that a linear combination of the variables will be stationary at level. This could also imply that the variables may be cointegrated. There is therefore need to carry out cointegration test that will test for the existence and possible number of cointegration that may exist among the variables. The Johansen and Juselius (1990) cointegration test is used to test the number of cointegrating vector among the variables using two likelihood ratio tests: maximum Eigen and trace values. The tests can be stated thus:

$$
\begin{aligned}
& \lambda_{\text {trace }}(r)=-T \sum_{i=r+t}^{n} \ln \left(1-\hat{\lambda}_{i}\right) \\
& \lambda_{\text {Max }}(r, r+1)=-T \ln \left(1-\hat{\lambda}_{r+1}\right)
\end{aligned}
$$

Where, $\hat{\lambda}_{i}$ is the estimated eigenvalue of the characteristics roots $r$, (with $r$ ranging from $0,1,2, \ldots, t$ ) and $\mathrm{T}$ is the number of observations. The null hypothesis for the trace statistics is to test whether number of the distinct cointegrating vectors is less or equal to $\mathrm{r}$. The null hypothesis of the maximum eigenvalue is to test whether the cointegrating vectors is less or equal to $r+1$.

\section{Discussion of Results}

We start the empirical analysis by looking at descriptive statistics of the variables in equation. The summary of the descriptive statistics is given in Table 1 below:

Table 1. Descriptive statistics

\begin{tabular}{lcccc}
\hline & MOP & RGDP & TFP & TOP \\
Mean & 9227.842 & 30723.60 & 0.808253 & 51.12563 \\
Median & 8531.587 & 22332.87 & 0.783077 & 53.03022 \\
Maximum & 13791.25 & 69023.93 & 1.000000 & 81.81285 \\
Minimum & 5264.881 & 13779.26 & 0.652365 & 21.44693 \\
Std. Dev. & 2497.846 & 17308.63 & 0.119078 & 16.58579 \\
Skewness & 0.258906 & 0.948702 & 0.381311 & -0.228185 \\
Kurtosis & 1.849923 & 2.519243 & 1.634151 & 2.073916 \\
& & & & \\
Jarque-Bera & 2.319927 & 5.587266 & 3.568742 & 1.554445 \\
Probability & 0.313498 & 0.061198 & 0.167903 & 0.459681 \\
& & & & \\
Sum & 322974.5 & 1075326. & 28.28886 & 1789.397 \\
Sum Sq. Dev. & $2.12 \mathrm{E}+08$ & $1.02 \mathrm{E}+10$ & 0.482106 & 9353.009 \\
& & & & \\
Observations & 35 & 35 & 35 & 35 \\
\hline
\end{tabular}


Table 1 is the summary of the descriptive statistics. The statistics shows that the average of industrial output and real GDP, within the period under consideration in Nigeria are 9227.8 and 30723.6 billion dollars respectively. While the average value of trade openness is 51.12 percent of real GDP and that of total factor productivity is 0.81 unit. The statistics shows that all the variables are normally distributed at 5 percent level of significance.

\subsection{Unit Root Test}

In empirical studies that involve the use of time series data, it is important to check each variable for the presence unit root. This is to enable the researcher determine the method of analysis to use so as to avoid obtaining spurious results which can occur when a non-stationary variable is used in traditional regression analysis. In this study we apply the Augmented Dick Fuller (ADF) and Phillip-Perron (PP) unit root tests on the four variables used to conduct our analysis. The ADF and PP were employed because of their reliability in controlling for higher order serial correlation and widely usage. The trend analyses of all the variables were conducted and it was found that the variables have trend and intercept. The results of ADF and PP are given in Table 2 below:

Table 2. ADF and PP Unit Root Test

\begin{tabular}{|c|c|c|c|c|c|}
\hline \multirow[t]{2}{*}{ Variable } & Level & \multicolumn{3}{|c|}{$1^{\text {st }}$ Diff. } & \multirow[t]{2}{*}{ Order of Integration } \\
\hline & ADF & PP & ADF & PP & \\
\hline \multirow[t]{2}{*}{ MOP } & -3.37 & -3.37 & $-5.43 * * *$ & $-5.56 * * *$ & $\mathrm{I}(1)$ \\
\hline & $(0.18)$ & $(0.17)$ & $(0.00)$ & $(0.00)$ & \\
\hline \multirow[t]{2}{*}{ RGDP } & -0.78 & -0.295 & $-3.31 *$ & $-3.32 *$ & $\mathrm{I}(\mathrm{I})$ \\
\hline & $(0.95)$ & $(0.98)$ & $(0.08)$ & $(0.08)$ & \\
\hline \multirow[t]{2}{*}{ TOP } & 0.47 & -2.35 & $-4.74 * * *$ & $-7.35 * * *$ & $\mathrm{I}(1)$ \\
\hline & $(0.383)$ & $(0.77)$ & $(0.00)$ & $(0.00)$ & \\
\hline \multirow[t]{2}{*}{ TFP } & -1.79 & -2.07 & $-3.68 * *$ & $-3.68 * *$ & $\mathrm{I}(1)$ \\
\hline & $(0.68)$ & (0.59) & $(0.03)$ & $(0.04)$ & \\
\hline
\end{tabular}

Notes: P-values in parenthesis. ** and *** means the coefficient is significant at $5 \%$ and $1 \%$.

Table 2 shows the summary of the results of the unit root tests for the variables in levels and first differences. The $\mathrm{ADF}$ and PP yield almost similar results. The result shows that all the variables are not stationary at level but become stationary after taking the first difference. After taking the first difference the MOP and TOP are stationary at 1 Percent level of significance while TFP and RGDP become stationary at 5 and 10 percent significance level respectively. The results reveal that all the variable are I(1), which could imply the possibility of the existence of cointegration among the variables. We therefore test for cointegration among the variables using the Johansen and Juselius (1990) cointegration test. The result of the Johansen cointegration is presented thus:

Table 3. Results of Johansen and Juselius Cointegration Test

\begin{tabular}{ccccc}
\hline \multicolumn{4}{l}{ Unrestricted Cointegration Rank Test (Trace) } \\
\hline Hypothesized No. of CE(s) & Eigenvalue & Trace Statistic & 0.05 Critical Value & Prob. $^{*}$ \\
\hline $\mathrm{R}=0$ & 0.52 & 39.68 & 47.85 & 0.23 \\
$\mathrm{R}=1$ & 0.29 & 15.32 & 29.79 & 0.75 \\
$\mathrm{R}=2$ & 0.07 & 3.62 & 15.49 & 0.93 \\
$\mathrm{R}=3$ & 0.03 & 1.047 & 3.84 & 0.30 \\
\multicolumn{5}{l}{} \\
\hline \multicolumn{5}{l}{ Hnrestricted Cointegration Rank Test (Maximum Eigenvalue) } \\
\hline $\mathrm{R}=0$ & Eigenvalue & Max-Eigen Statistic & 0.05 Critical Value & Prob.* \\
$\mathrm{R}=1$ & 0.52 & 24.36 & 27.58 & 0.12 \\
$\mathrm{R}=2$ & 0.29 & 11.69 & 21.13 & 0.57 \\
$\mathrm{R}=3$ & 0.07 & 2.57 & 14.26 & 0.97 \\
\hline
\end{tabular}

*MacKinnon-Haug-Michelis (1999) p-values 
Table 3 is the result of the Johansen and Juselius cointegration test. The trace and Max-eigenvalue statistics indicates that there is no cointegration among the variables at 5 percent significance level as all the calculated trace and eigenvalues fall below their respective critical values. This indicates that it is better to use the vector auto regressive (VAR) method to estimate the long run relationship among the variables. The estimated VAR model is shown thus:

Table 4. Vector Autoregression (VAR) Estimates

\begin{tabular}{|c|c|c|c|c|}
\hline & $\triangle \mathrm{MOP}$ & $\Delta$ RTOP & $\Delta$ RGDP & $\triangle \mathrm{TFP}$ \\
\hline$\Delta \mathrm{MOP}(-1)$ & $\begin{array}{c}0.329 * * * \\
{[1.639]}\end{array}$ & $\begin{array}{c}2.655^{* * * *} \\
{[1.899]}\end{array}$ & $\begin{array}{c}0.542 \\
{[1.561]}\end{array}$ & $\begin{array}{c}-2.00 \mathrm{E}-07 \\
{[-0.015]}\end{array}$ \\
\hline$\Delta \mathrm{MOP}(-2)$ & $\begin{array}{c}0.289 \\
{[1.242]}\end{array}$ & $\begin{array}{c}0.156 \\
{[0.096]}\end{array}$ & $\begin{array}{c}0.476 \\
{[1.184]}\end{array}$ & $\begin{array}{c}-2.74 \mathrm{E}-06 \\
{[-0.177]}\end{array}$ \\
\hline$\Delta \mathrm{RTOP}(-1)$ & $\begin{array}{c}0.037 \\
{[1.203]}\end{array}$ & $\begin{array}{c}0.359 * * * \\
{[1.636]}\end{array}$ & $\begin{array}{c}0.065 \\
{[1.201]}\end{array}$ & $\begin{array}{l}2.20 \mathrm{E}-06 \\
{[1.053]}\end{array}$ \\
\hline$\Delta \mathrm{RTOP}(-2)$ & $\begin{array}{c}0.048 * * * \\
{[1.617]}\end{array}$ & $\begin{array}{c}0.303 \\
{[1.459]}\end{array}$ & $\begin{array}{c}0.044 \\
{[0.862]}\end{array}$ & $\begin{array}{c}-1.60 \mathrm{E}-07 \\
{[-0.080]}\end{array}$ \\
\hline$\Delta \mathrm{RGDP}(-1)$ & $\begin{array}{c}0.117 \\
{[0.541]}\end{array}$ & $\begin{array}{c}0.283 \\
{[0.187]}\end{array}$ & $\begin{array}{r}0.862 \\
{[2.30]}\end{array}$ & $\begin{array}{l}\text { 7.88E-06 } \\
{[0.548]}\end{array}$ \\
\hline$\Delta \mathrm{RGDP}(-2)$ & $\begin{array}{c}0.150694 \\
{[0.658]}\end{array}$ & $\begin{array}{c}-1.268 \\
{[-0.796]}\end{array}$ & $\begin{array}{c}0.031 \\
{[0.081]}\end{array}$ & $\begin{array}{c}-8.77 \mathrm{E}-06 \\
{[-0.578]}\end{array}$ \\
\hline$\Delta \mathrm{TFP}(-1)$ & $\begin{array}{c}6782.63 \\
{[1.335]}\end{array}$ & $\begin{array}{l}56690.75 \\
{[1.603]}\end{array}$ & $\begin{array}{l}-5645.087 \\
{[-0.64269]}\end{array}$ & $\begin{array}{c}0.208 \\
{[0.620]}\end{array}$ \\
\hline$\Delta \mathrm{TFP}(-2)$ & $\begin{array}{c}4553.15 \\
{[0.950]}\end{array}$ & $\begin{array}{l}25426.21 \\
{[0.762]}\end{array}$ & $\begin{array}{c}6425.74 \\
{[0.775]}\end{array}$ & $\begin{array}{c}0.100 \\
{[0.315]}\end{array}$ \\
\hline $\mathrm{C}$ & $\begin{array}{c}376.9 * * \\
{[2.461]}\end{array}$ & $\begin{array}{c}2129.8 * * * \\
{[1.997]}\end{array}$ & $\begin{array}{c}447.4 * * * \\
{[1.689]}\end{array}$ & $\begin{array}{c}0.007 \\
{[0.683]}\end{array}$ \\
\hline R-squared & 0.965 & 0.878 & 0.998 & 0.952 \\
\hline F-statistic & $\begin{array}{r}83.09 \\
-24875\end{array}$ & $\begin{array}{r}21.63 \\
-30916\end{array}$ & $\begin{array}{l}1825.06 \\
-262.70\end{array}$ & $\begin{array}{l}60.37 \\
73.57\end{array}$ \\
\hline Akaike AIC & 15.51 & 19.39 & 16.61 & -3.72 \\
\hline Schwarz SC & 15.92 & 19.80 & 17.02 & -3.31 \\
\hline
\end{tabular}

Notes: P-values in parenthesis. *** and $* *$ means the coefficient is significant at $10 \%$ and $5 \%$ respectively.

The results in Table 4 present the estimates of the long run coefficients of the VAR model. All the variables are in their first difference. The results show that for the equation of the industrial output (MOP), the lag of MOP and second lag of TOP are significant and positive at 10 percent level of significance. In the equation for trade openness, 
the first lags of MOP and TOP are found to be significant and positive at 10 percent level of significance. The result implies that trade openness has a significant effect on industrial output than the other macroeconomic variables under consideration. This finding is consistent with Adenikinju and Olofin (2000) position that trade openness and policy of trade give rise to industrial development.

\subsection{MOP Response to RGDP, TFP and TOP Shocks}

We used the impulse response function to examine and identify the responsiveness of the dependents variables in a VAR system when there is a shock in the error term (innovation) of each of the equation in the VAR model specified in equation 1-4. The setting of the order of innovation follow the Cholesky adjusted method. The impulse response graph is shown in the table below:
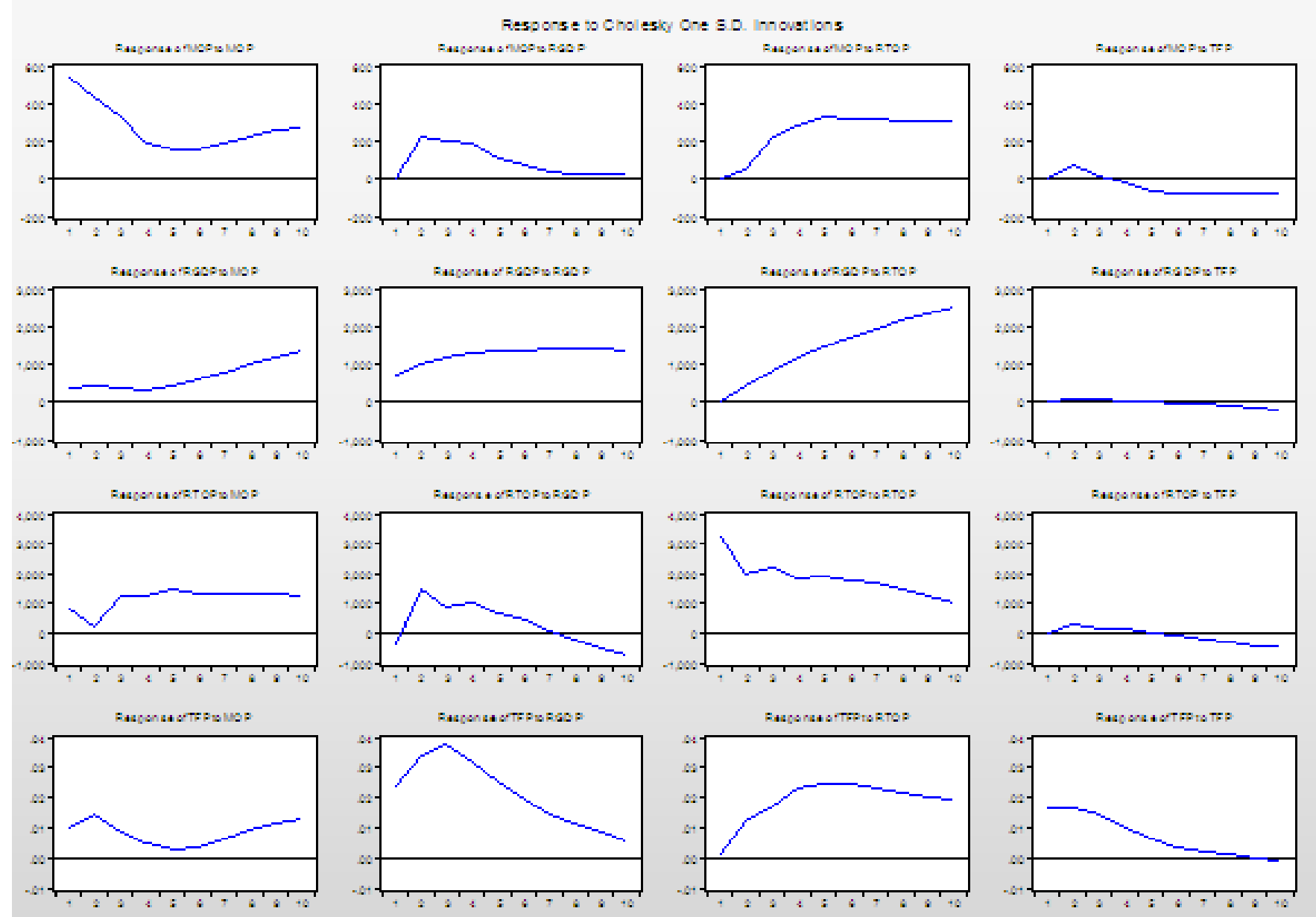

Figure 1. Impulse Response Function (Cholesky one S.D innovation)

Figure 1 shows the impulse response of function graph. The response of industrial output to real GDP (RGDP), total factor productivity (TFP) and Trade openness (TOP) is examined using the Cholesky one standard innovation in this section. The aim is to find out the effect of unanticipated shocks in real GDP, TFP and TOP on output in the industrial sector. The graphs of a Cholesky one standard innovation show the actual impulse response functions for each of the endogenous variables given that, each asymptotically deviated from the normal path. In the first row of Figure 1 the dynamic responses of the effect of industrial output on industrial output (itself) is found to be persistent and positive over the period of ten years. The impact of RGDP on industrial output is significant and positive over the period but started dropping after the second year and get close to zero towards the end of the tenth year. This implies that a positive RGDP will cause output in the industrial sector to increase over time but this increase will decrease over time. This finding approximate Odior (2013) position, that higher productivity is a sure means of enhancing economic growth and rising standards of living in any country. On impact of trade openness (TOP), the 
graph shows that the impact of TOP on industrial output is positive and persistent over the entire period. This indicates that a positive TOP causes output in the industrial sector to increase overtime. This agrees with the finding of Ebong, Udo and Obafemi (2014), that trade openness had a positive influence on industrial development. The effect of total factor productivity (TFP) is positive in the first two years but become negative after the third year after which it remained negative and significant for the remaining period. This implies that in the short run TFP exhibit positive impact on industrial output, however, in the long run, it will continue to have a negative impact on industrial output. The results show that RGDP and TOP has positive and significant impact on industrial sector both in Nigeria in the short run and long run. The impact of the total factor product is shown to be positive only in the first two years. This analysis is very important particularly in a developing country like Nigeria in locating channels and avenues that is important in improving the growth in the industrial sector.

\subsection{Variance Decomposition Analysis}

To further substantiate the analysis of the dynamic interactions and strength of the causal relationship among the variables in the system, we carried out the variance decomposition analysis so as to determine the degree to which a shock in any of the variables is reflected in output of the industrial sector. In this study we are mostly concern on the fluctuation in the industrial output as such only the variance decomposition of MOP is presented. The variance decomposition analysis of the industrial output is shown below:

Table 5. Result of Variance Decomposition

\begin{tabular}{cccccc}
\hline \multicolumn{5}{c}{ Variance Decomposition of MOP } \\
\hline Period & S.E. & MOP & RGDP & TOP & TFP \\
\hline 1 & 519.35 & 100.00 & 0.00 & 0.00 & 0.00 \\
2 & 711.20 & 83.039 & 12.42 & 3.48 & 1.05 \\
3 & 862.43 & 67.64 & 20.16 & 11.40 & 0.79 \\
4 & 955.09 & 59.69 & 23.56 & 16.08 & 0.64 \\
5 & 1012.37 & 56.43 & 23.50 & 19.25 & 0.81 \\
6 & 1050.03 & 54.93 & 22.52 & 21.33 & 1.21 \\
7 & 1081.22 & 53.88 & 21.32 & 22.99 & 1.79 \\
8 & 1109.31 & 52.90 & 20.26 & 24.42 & 2.41 \\
9 & 1136.55 & 51.93 & 19.30 & 25.77 & 2.99 \\
10 & 1163.39 & 50.99 & 18.42 & 27.09 & 3.48 \\
\hline \multicolumn{5}{c}{ Cholesky Ordering: MOP RGDP TFP TOP } \\
\hline
\end{tabular}

Table 5 is the result of variance decomposition analysis of industrial output (MOP). The result depicts the variation of MOP to MOP, RGDP, TOP and TFP over the period of 10 years. In the short run of year 4, the shock to MOP account for about 59.7 percent variation in MOP (that is as a result of own shock). A shock in RGDP causes 23.56 percent fluctuation in the output of the industrial sector. In the case of trade openness, shocks in TOP causes 16.09 percent variation in the output of industrial sectors. While shocks in the total factor productivity causes only 0.65 percent fluctuation in the output of industrial sectors. In the long run the result shows that the impact of TOP on the variation of MOP significantly increases to 27.09 percent while the effects of MOP and RGDP reduced to 50.9 and 18.4 respectively. The effects of TFP increase a little to 3.4 percent. This implies that the effect of TOP persists and continuous impact on MOP in Nigeria. Thus trade openness is important for growth in the industrial sector of Nigeria. Increase in import and export activities increases the output of the industrial sector.

\section{Conclusion and Recommendations}

This paper employs the Vector Autoregressive (VAR) analysis to measure the effect of trade openness and total factor productivity on industrial output in Nigeria. The impulse response function and variance decomposition shows an increasing and positive impact of trade openness on industrial output in Nigeria, while the total factor productivity 
exhibit a negative influence on industrial output in the long run. We also find that real GDP influences industrial output positively. Our findings imply that that an increase in trade openness has a greater effect on industrial output than total factor productivity and GDP. This suggests that an increase activity in export and import is veritable factor in the development of industrial sector in Nigeria. Thus, government should imbibe policies that encourage international trade.

\section{References}

Adenikinju, A., \& Olofin, S.O. (2000). Economic policy and manufacturing sector growth performance in Africa: The Nigeria Journal of Economic and Social Studies, 42(2), 1-14.

Adesina, A.O. (1992). Productivity trends in Nigeria. Seminar paper Department of economics, University of Ibadan.

Alao, R. O. (2010). Productivity in the Nigerian Manufacturing Sub-Sector Error Correction Model (ECM). European Journal of Economics, Finance and Administrative Sciences, (20).

Aluko, M.A.O., Akinola, G.O., \& Fatokun, S. (2004). Globalization and the Manufacturing Sector: A Study of Selected Textile Firms in Nigeria. Journal of Social Science, 9(2), 119-130. https://doi.org/10.1080/09718923.2004.11892440

Anyanwu, C. M. (2004). Productivity in the Nigerian Manufacturing Industry. Research Department, CBN.

Ebong, F., Udo, E., \& Obafemi, F. (2014). Globalization and Industrial Development of Nigeria: Evidence from Time Series Analysis. International Review of Social Sciences and Humanities, 6(2), 12-24.

Grossman, G., \& Helpman, E. (1991). Innovation and Growth in the Global Economy. MIT Press, MA.

Grossman, G.M., \& Helpman, E. (1989). Growth and Welfare in a Small Open Economy. NBER Working Paper No. 2970, July. National Bureau of Economic Research, Cambridge, Massachusetts. https://doi.org/10.3386/w2970

Hulton C. W. (1967). Exports expansion and economic growth: A survey. Land Economics, 43, 148-157. https://doi.org/10.2307/3145238

Johansen, S., \& Juselius, K. (1990). Maximum Likelihood Estimation and Inference on Cointegration with Application to the Demand for Money. Oxford Bulletin of Economics and Statistics, 52(2), 169-210. https://doi.org/10.1111/j.1468-0084.1990.mp52002003.x

Lucas, R.E. Jr. (1988) On the Mechanics of Economic Development. Journal of Monetary Economics, 22, 73-89. https://doi.org/10.1016/0304-3932(88)90168-7

Obasan, K. A., \& Adediran, O. (2010). The Role of Industriliation in the Economic Development of Nigeria. Journal of Management and Society, 1(2), 1-16.

Odior, E.S. (2013). Macroeconomic Variables and the Productivity of the Manufacturing Sector in Nigeria: A Static Analysis Approach. Journal of Emerging Issues in Economics, Finance and Banking, 1(5), 362-380.

Okafor, E.E. (2005). Globalization and Work: The Nigerian Experience. Journal of Society, Development and Public Health, 2, 21-47.

Richardo, D. (1817). On The Principles of Political Economy and Taxation (3rd ed.). John Murray, London.

Romer, P.M. (1990). Endogenous Technological Change. Journal of Political Economy, 98. https://doi.org/10.1086/261725

Smith, A. (1776). An inquiry into the Nature and causes of the wealth of Nations (3rd ed.). Clarendo press, Oxford. https://doi.org/10.1093/oseo/instance.00043218

Tawose, J. (2012). Effects of Public Expenditure on Industrial Sector Productivity in Nigeria. Canadian Social Science, 89(1), 204-214.

Ugwuanyi, C.U., \& Nkem, M.N. (2017). Industrialization Drivers and Nigeria Economic Growth. International Journal of Science and Research Methodology, 6(4).

Umoru, D., \& Eboriem, M. (2013). Trade Liberalization and Industrial Growth in Nigeria. Journal of Poverty, Investment and Development, 1(1), 148-156. 